\title{
Forage quality, intake, and digestibility of year- long pastures for steers
}

\author{
P.B. KLOPPENBURG, H.E. KIESLING, R.E. KIRKSEY, AND G.B. DONART
}

\begin{abstract}
Authors are former graduate student and professor emeritus, Dept. of Animal and Range Sci., N.M. State Univ., Las Cruces, 88003; superintendent, Agricultural Science Center, Tucumcari, NM, and Professor, Dept. of Animal and Range Sci., N.M. State Univ., Las Cruces, 880003. Present address for Kloppenburg: Farmland Industries, Inc., Artesia, N.M. 88210 .
\end{abstract}

Abstract

Thirty-six weanling steer calves (avg wt $=174 \pm 14 \mathrm{~kg}$ ) were grazed on either wheat, irrigated improved, or native rangeland pastures from December 1989 to December 1990. Irrigated improved pastures consisted of 2 cool-season [tall wheatgrass [Agropyron elongatum (Host.) Beauv.], tall fescue (Festuca arundinacea Schreb.) 2 warm-season [bermudagrass (Cynodon dactyIon (L.) Pers.], bluestem (Bothriochloa ischaemum Keng.), and annual wheat. Wheat pastures were grazed from 13 December to 11 April. Warm-season pastures were grazed from 30 May (bermudagrass) or 27 June (bluestem) until 3 October. Cool-season pastures were grazed at other days during spring and fall seasons. Rumen evacuation procedures were used to evaluate forage quality and estimate forage intake during each grazing season. Winter rangeland pastures were lower in nutritional quality (based on protein and fiber contents) and in vitro organic matter digestibility ( 53 vs $85 \%, P<0.05$ ) compared to wheat pasture. During spring, rangeland pastures were still lower in protein and higher in fiber but in vitro organic matter digestibility $(72,73,72 \%$; respectively, for wheatgrass, fescue and rangeland) was similar $(P=0.70)$ for all forages. Rangeland and warm-season pastures were similar in quality during summer but rangeland pastures were higher $(P<0.10)$ in in vitro organic matter digestibility $(65,69$, and $73 \%$; respectively, for bermudagrass, bluestem, and rangeland). Rangeland pastures were again lower in quality and digestibility than cool-season grasses during the fall. There were no difference $(P>0.10)$ in organic matter intake (\% of body weight) during winter, summer, and fall season but during spring organic matter intake was greater $(P<0.10)$ for steers on rangeland pasture than for those on cool-season grasses.

Key Words: irrigated pastures, rangeland pasture, quality, intake

This research was supported by the New Mexico Agr. Exp. Sta., Las Cruces and was part of project 1-3-42215.

Manuscript accepted 15 Feb. 1995.
High temperatures seem to be the dominant factor limiting growth and quality of cool-season grasses in the summer. Fales (1986) found high temperatures caused a reduction of cell-wall digestibility by increasing amount of indigestible cell wall without affecting rate of digestion of the more labile fraction. Ford et al. (1979) reported increased temperatures have been associated with variations in concentrations of cellulose, hemicellulose, and lignin.

Because of arid conditions in the Southwest, many producers use irrigated pastures to increase their production potential (Wallace and Williams, 1979). Kirksey et al. (1991) reported animals grazing sainfoin had the highest season-long average daily gain, but lowest carrying capacity. Switchgrass had one of highest carrying capacities and early-season average daily gain, but late-season average daily gain was poor. The sainfoin-wheatgrass pasture was among the most productive pastures in terms of gain per ha and carrying capacity. On a season-long basis, tall wheatgrass had one of the poorest average daily gain, but had among the highest carrying capacities. Wallace and Williams (1979) reported beef production and average daily gain per ha favored fescue over wheatgrass and orchardgrass. Digestibility of dry matter, organic matter, fiber and crude protein were not different among species. Fisher et al. (1991) reported bermudagrass had the lowest in vitro dry matter digestibility when compared to tall fescue, flaccidgrass, and switchgrass. Bermudagrass and switchgrass had the highest proportion of stem in their canopy. Burns et al. (1991) found steers grazing bermudagrass had the lowest average daily gain when compared to flaccidgrass and switchgrass, and average daily gain was associated with an increased in vitro dry matter digestibility. These authors suggested quality of the bermudagrass canopy was inferior to tall fescue, flaccidgrass and switchgrass which have canopy structures conducive to high average daily gain. Thus, proper management of these forages shifts animal performance limitations to the animal. Conversely, the bermudagrass canopy is not conducive to high average daily gain (Burns et al. 1991, Fisher et al. 1991). A study was conducted to evaluate different animal management systems to provide high quality forage on a year-round basis, using rangeland, winter wheat, and irrigated pastures consisting of cool- and warm-season perennial grasses. Diet quality, forage intake, digestibility, and animal performance were measured to characterize nutritive traits of the forages in different seasons of the year. 


\section{Experimental Procedures}

The irrigated pastures used in this trial were composed of 2 cool-season perennial grasses; Jose tall wheatgrass [Agropyron elongatum (Host) Beauv.)] and Johnstone tall fescue (Festuca arundinacea Schreb.), and 2 warm-season perennial grasses, Hardie bermudagrass [Cynodon dactylon (L.) Pers.] and Ironmaster old world bluestem (Bothriochloa ischaemum Keng.). All pastures were located at the New Mexico State University (NMSU) Agricultural Science Center at Tucumari, N.M. Coolseason pastures measured 1.6 ha and warm-season pastures were 1.2 ha. Furrow irrigation was used in all pastures with row spacing of $102 \mathrm{~cm}$. All pastures were replicated (8 total) and located adjacent to one another. The 2 rangeland pastures used in this trial measured 6.5 ha. Dominant grasses found in these pastures included; blue grama [Bouteloua gracilis (H.B.K.) Lag. ex Steud.], sideoats grama [Bouteloua curtipendula (Michx.) Torr.], and sand dropseed [Sporobous cryptandrus (Torr.) A. Grey]. Sub-dominant grasses consisted of yellow bluestem, threeawns (Aristida spp.), lovegrass (Eragrostis spp.), vine mesquite (Panicum obtusum H.B.K.), and silver bluestem [Bothriochloa saccharoides (SW. Rydb.]. The rangeland pastures were in good condition containing some introduced grasses intermixed with native species. Overall, the rangeland pastures were composed of good quality warm-season grasses. The rangeland pastures were not subjected to any cultural practices. Two 2.8 ha pastures of winter wheat (Triticum aestivum L.) were utilized in this trial. Wheat pastures were planted at a seeding rate of $78 \mathrm{~kg} / \mathrm{ha}$ in early September 1989 and received a single fall irrigation. The wheat pastures were not fertilized and no cultural practices were applied during the grazing trial.

The site consisted mainly of a fine-loamy (fine-silty), mixed, thermic soil. Mean maximum temperature ranged from $10^{\circ} \mathrm{C}$ in December to $37^{\circ} \mathrm{C}$ in June and averaged $23^{\circ} \mathrm{C}$ for the year. Mean minimum temperatures were $-7^{\circ} \mathrm{C}$ and $19^{\circ} \mathrm{C}$ for December and June and averaged $7^{\circ} \mathrm{C}$ for the year. Total rainfall for the year was $394 \mathrm{~mm}$ with $60 \%$ falling during July, August, and September. Cool-season pastures received 3 irrigations in the spring for a total of 2,837 cubic meters $(2.3 \mathrm{ac} \mathrm{ft})$ of water while warm-season pasture received 3 applications for a total of 3,207 cubic meters ( $2.6 \mathrm{ac} \mathrm{ft}$ ) of water. Nitrogen was applied at 187 $\mathrm{kg} / \mathrm{ha}$ in 2 applications to cool-season grasses and $306 \mathrm{~kg} / \mathrm{ha}$ in 3 applications to warm-season grasses.

Three animal management strategies were used to examine forage composition, intake, and in vitro organic matter digestibility of weanling steers on a seasonal and year-long basis. Group 1 (12 steers) grazed annual wheat in winter, wheatgrass in spring, bluestem in summer, and wheatgrass in the fall. Group 2 (12 steers) grazed annual wheat in the winter, tall fescue in spring, bermudagrass in summer, and tall fescue in the fall. Group 3 (12 steers) grazed rangeland pastures the entire year. Stocking rates (steers/ha) were held constant on all pastures during each grazing season (2.1 for wheat, 3.75 for cool-season, 5 for warm-scason, and 0.9 for rangeland). All animals had free access to water, salt, and mineral blocks ${ }^{1}$ during the study period. Fourteen steers fitted with indwelling ruminal cannulas were used to collect forage samples and characterize diet quality and intake of steers on the different pastures.

\footnotetext{
Purina Mineral Block 12:12 VAK, No. 3786, Purina Mills, Inc., St. Louis, Mo. 63166.

${ }^{2}$ Captec Pty. Ltd., 103 Pipe Road, Laveron, Victoria, Austr.
}

To minimize labor and handling stress, a continuous release chromic oxide capsule (Captec Chrome ${ }^{2}$ ) was administered as an external marker at a known rate, in order to estimate fecal output (Laby et al. 1985; Barlow et al. 1988; Kattnig, 1991). Two intact steers, as well as 2 cannulated steers from each pasture were dosed with chromic oxide capsules. Capsules were administered into the reticulo- rumen of intact steers using a commercial stainless steel spring balling gun ${ }^{3}$ and directly through the cannula in the ruminally fistulated animals.

Fecal sampling began 9 days post-dosing (Kattnig 1991). Fecal samples were also collected from steers that were not dosed with chronmic oxide treated in a similar fashion to other samples, and used to correct for background interference when analyzed for $\mathrm{Cr}$ content.

Steers were held in pens overnight the evening before sampling without access to feed, but with free access to water. Fecal grab sampling began at sunrise each day, and continued for 4 consecutive days. Fecal samples were placed in labeled plastic bags and immediately frozen at $-20^{\circ} \mathrm{C}$. After sampling, steers were placed back on assigned pastures and allowed to graze until sundown when they were again gathered and penned.

Fecal samples were maintained frozen until laboratory analysis were conducted. Samples were placed in a forced-air oven and dried $\left(50^{\circ} \mathrm{C}\right)$ for 48 hours. Dried samples were ground in a Wiley mill to pass a 2-mm screen. Dried fecal samples were subsampled composited by steer over the 4-day collection period and stored in air-tight containers until analysis for $\mathrm{Cr}$ content could be conducted.

Fecal dry matter and ash were determined by standard procedures (AOAC, 1984). Chromium concentration was determined according to procedures outlined by Williams et al. (1962) by atomic absorption spectroscopy using a nitrous oxide-acetylene flame (Galyean, 1988). All samples were analyzed in duplicate with a maximum acceptable coefficient of variation of $\leq 5 \%$. Fecal output was estimated by:

$$
\text { Fecal output, } g / \text { day }=\frac{\text { Indicator consumed, } g / \text { day }}{\text { Indicator conc. in feces }(g / g \text { dry matter })}
$$

Only cannulated steers from each pasture were used for diet sampling. Diet sampling procedures began after fecal collections were made on the third and fourth sampling days. Cannulated steers were placed in a squeeze chute, and the reticulo-rumen of each steer was completely evacuated. Upon removal of ruminal contents, the rumen wall was wiped with a damp sponge to remove any debris clinging to the inner rumen wall. Ruminal contents were placed in a large rubber container and sealed. Once evacuation was completed, steers were placed on assigned pastures and allowed to graze undisturbed for approximately $45 \mathrm{~min}$. Steers were then gathered from pastures and penned. Freshly ingested forage was collected via fistula, and original ruminal contents were replaced in the animal. Diet samples were frozen immediately at $-20^{\circ} \mathrm{C}$. After sample collections, all animals were allowed to graze their respective pastures undisturbed until they were gathered again in the evening.

Diet samples were transported to the main campus in the same manner as fecal samples. To prevent compositional changes from conventional oven-drying procedures (Karn, 1986; Burritt et al., 1988; Kloppenburg et al., 1990), ingesta samples were freeze-

$\sqrt[3]{\text { German Hauptner Balling Gun, Quad Five, Ryegate Mont } 59074 .}$ 
dried as outlined by Kloppenburg et al. (1990). Dried samples were ground in a Wiley mill to pass a 2 -mm screen and composited by steer over sampling days.

In vitro digestion analyses were conducted on ruminal composite digesta samples. Ruminal inoculum was taken from 2 steers fed an alfalfa diet. The Tilley and Terry (1963) 2-stage technique ( 48 hour ruminal inoculum +48 hour acid pepsin) was used to estimate extent of in vitro organic matter disappcarance (in vitro organic matter digestibility). Forage indigestibility was calculated by: 100 - in vitro organic matter digestibility. Once indigestibility was known, organic matter intake (OMI) per day was calculated by the following:

$$
\text { OMI, g/day }=\frac{\mathrm{FO}, \mathrm{g} / \mathrm{day}}{\% \mathrm{OM} \text { indigestibility }}
$$

Forage dry matter and ash were determined by procedures of the AOAC (1984). Neutral detergent fiber, acid detergent fiber, and acid detergent lignin analyses were conducted according to procedures of Goering and Van Soest (1970). Insoluble unavailable $\mathrm{N}$ is reported as acid detergent insoluble nitrogen, or the nitrogen present in residues following acid detergent fiber analysis. Kjeldahl procedures were used for all nitrogen analysis including crude protein and acid detergent insoluble nitrogen (AOAC, 1984).

On 13 December, crossbred weanling steers (avg. body weight $174 \pm 14 \mathrm{~kg}$ ) were sorted randomly into uniform groups and placed on either winter wheat or range pastures. Two replications of each pasture type were used. Additional steers were maintaincd on separate wheat pastures for use in later grazing pcriods, when more pastures were added to the study. Four intact and 2 cannulated steers were assigned randomly to each replication of each pasture. Cannulated steers were used to sample available forage for diet quality and digestibility. Steers remained on winter pastures from 13 December 1989, through 11 April 1990 and were weighed periodically; however, only total season gains was analyzed. Steers grazing rangeland pastures were supplemented with $20 \%$ crude protein cubes ${ }^{4}$ at the rate of $0.45 \mathrm{~kg}^{\circ} \mathrm{hd}^{-1} \bullet \mathrm{d}^{-1}$ from 9 February until 18 March. From 19 March to 27 April range steers were supplemented at the rate of $0.68 \mathrm{~kg} \cdot \mathrm{hd}^{-1} \cdot \mathrm{d}^{-1}$. During periods of snow cover (5 days in January) steers on wheat received grass hay ( $5 \mathrm{~kg} /$ head daily) of medium to low quality. Steers on rangeland received $5 \mathrm{~kg} /$ head for 2 days during that time. On 5 March 1990, 4 steers ( 2 cannulated and 2 intact) in each pasture ( 2 range and 2 wheat) were dosed with continuous release chromic oxide capsules. On 14 March fecal grab sampling began, and continued daily through 17 March. Diet sampling procedures occurred on 16 and 17 March as outlined previously.

On 11 April 1990, 24 steers, which were previously grazing wheat pastures, were rotated to cool-season pastures (tall fescue or wheatgrass). As in the winter period, 6 animals were allotted randomly to each cool-season pasture (4 intact, 2 cannulated). Steers that grazed rangeland pastures during the winter remained on the same pastures. In order to assess diet quality, digestibility and intake of all steers, fecal and ruminal samples were collected as in the winter period. Chromium dosing occurred on 21 May, and fecal sampling was accomplished between 21 May and 24 May. Diet sampling occurred on 23 and 24 May. Forage sam-

Purina Forage Balances Cub 3N, No. 3422, Purina Mills, Inc., St. Louis, Mo. 63166. pling took place as previously explained. Animals wcre weighed on 11 April, 2 May, 30 May, and 27 June; however gains were compared only when steers were grazing seasonal pasture simultaneously.

On 30 May, steers grazing tall fescue were moved to bermudagrass pastures. Steers grazing wheatgrass were rotated to bluestem pastures on 27 June. Steers remained on warm-season pastures until 3 October. Forage sampling also occurred as in spring. Chromium dosing was accomplished on 21 July, and fecal grab samples were taken 30 July-2 August. Diet samples were taken on 1 and 2 August. Steer gains were compared for total season only.

On 3 October, steers on bluestem were moved back to original wheatgrass pastures. Steers grazing bermudagrass were placed on tall fescue pastures. Test steers remained on cool-season pastures until 12 December, which ended the year's experiment. Fecal grab samples were obtained 1-4 November, and diet samples were collected 3 and 4 November. As in previous seasons, steer gains were compared for total season only.

Forage production data were collected during the spring, summer, and fall to assess seasonal forage dry matter yield (DMY). Three exclosures $\left(4.5 \mathrm{~m}^{2}\right)$ were randomly erected in the upper, middle, and lower one-third of each pasture. Pastures were sampled immediately prior to grazing, at each animal weigh day, an when grazing was terminated each season. On each sampling day, the aerial portion of the grass was hand clipped from 2 plots $(30.5$ $\times 102 \mathrm{~cm}$ ) in the caged areas. The freshly clipped samples were weighed and placed in a forced-air oven $\left(50^{\circ} \mathrm{C}\right)$ for 48 -hour. Once dried samples were reweighed and weights recorded. Dry matter yield (DMY) was calculated using these samples:

$$
\text { DMY = End dry weight - Start dry weight. }
$$

End dry weight is defined as samples collected from inside exclosures at the end of the grazing period; and start dry weight is defined as samples collected from inside exclosures at the start of the period.

Data were analyzed as a completely randomized design by methods described by Steele and Torrie (1980) with analysis of variance conducted using GLM procedures of SAS (1985). Variables were examined by season, and all treatment means were compared by Least Significant Difference when the overall treatment $\mathrm{F}$ was significant $(P<0.10)$. In all cases the experimental unit was the pasture. The $n$ values given in tables are number of observations used for determining standard errors.

\section{Results and Discussion}

\section{Winter}

Wheat pastures were higher $(P<0.05)$ in crude protein and available crude protein, and lower in acid detergent insoluble nitrogen than range pastures (Table 1). Neutral detergent fiber and acid detergent fiber were similar $(P=0.10$ and 0.13 , respectively) between pasture types, but wheat pastures tended to have lower values. Acid detergent lignin was higher $(P<0.05)$ in rangeland pastures compared to wheat. Winter wheat had greater $(P<0.05)$ in vitro organic matter digestibility when compared to rangeland pastures ( 85 vs $53 \%$; Table 1 ). Since the rangeland pastures were primarily made up of warm-season grasses, forage available to steers consisted predominantly of dormant grass 
Table 1. Chemical composition (organic matter basis), in vitro organic matter disappearance (IVOMD) of ingesta and intake of steers grazing either winter wheat or rangeland pastures during the winter grazing period of 1990.

\begin{tabular}{|c|c|c|c|c|}
\hline \multirow[b]{2}{*}{ Item } & \multicolumn{2}{|c|}{ Pasture } & \multirow[b]{2}{*}{$S E^{\mathrm{a}}$} & \multirow[b]{2}{*}{$\operatorname{OSL}^{b}$} \\
\hline & Wheat & Range & & \\
\hline $\mathrm{CP}(\mathscr{C})$ & 26 & 11 & 1.5 & 0.02 \\
\hline Available CP (\%) & 24 & 8 & 1.4 & 0.01 \\
\hline $\operatorname{ADN}(\%$ of $N)$ & 6 & 31 & 3.6 & 0.04 \\
\hline $\mathrm{NDF}(c)$ & 52 & 92 & 9.9 & 0.10 \\
\hline $\mathrm{ADF}(\mathscr{C})$ & 36 & 69 & 9.3 & 0.13 \\
\hline $\mathrm{ADL}(\%)$ & 4 & 11 & 0.5 & 0.01 \\
\hline \multicolumn{5}{|l|}{ Dry matter basis } \\
\hline Intake $(\mathrm{kg})$ & 6.3 & 4.8 & 1.6 & 0.57 \\
\hline Intake ( $\% \mathrm{BW})$ & 2.8 & 2.7 & 0.7 & 0.97 \\
\hline \multicolumn{5}{|c|}{ Organic matter basis } \\
\hline Intake $(\mathrm{kg})$ & 4.0 & 3.7 & 0.8 & 0.83 \\
\hline Intake (\% BW) & 1.8 & 2.2 & 0.5 & 0.52 \\
\hline IVOMD (\%) & 85.3 & 53.1 & 0.3 & $<0.01$ \\
\hline
\end{tabular}

atrandard error $(n=4)$.

bobscrved significance level.

species. Therefore, it is not surprising that analysis of chemical components of the ingesta revealed winter wheat was of much higher quality.

No differences $(P>0.10)$ were observed in intake when expressed as percentage of body weight or total intake $(\mathrm{kg})$ on either an organic matter basis or dry matter basis (Table 1). Values obtained for organic matter intake as percent body weight are similar to results from Rosiere (1978), who reported intake levels equal to $1.5 \%$ body weight for heifers grazing wheatgrass and $1.2 \%$ body weight for heifers grazing tall fescue pastures in mid-June. McCollum et al. (1985) indicated a decrease in forage intake is normally associated with decreased forage quality. However, intake was not different between steers grazing winter wheat and rangeland pastures. This suggests gut-fill of steers on rangeland pastures may have increased, thereby allowing a greater intake than normally would be possible. Funk et al. (1987) suggested when available forage is not limiting poor quality forage intake may not decrease because gastrointestinal fill may increase to compensate for decreased digestibility or passage rate. Stocking rate ( 0.9 steers/ha) on rangeland was light enough to insure adequate forage available. Further, Hutton (1963) observed a decrease in consumption for cows grazing forage with digestibility greater than $70 \%$.

\section{Spring}

Differences in chemical composition of ingesta were evident among tall fescue, wheatgrass, and rangeland pastures (Table 2). Tall fescue pastures were highest $(P<0.10)$ in crude protein and available crude protein, followed by wheatgrass and rangeland. Acid detergent insoluble nitrogen was similar among all pastures $(P>0.10)$. Fiber components were also similar between wheatgrass and tall fescue. Rangeland pastures, however, contained more neutral detergent fiber $(P<0.05)$ and acid detergent fiber $(P$ $<0.10)$ than either wheatgrass or tall fescue. All three pasture types were similar in acid detergent lignin $(P>0.10)$. These data suggest that although differences were present among all pastures in crude protein and available crude protein, each pasture type supplied crude protein in amounts great enough to allow acceptable gains. Steers grazing wheatgrass, tall fescue, and rangeland had similar organic matter intake $(P<0.10)$ when expressed as $\mathrm{kg} / \mathrm{d}$ (Table 3). However, when organic matter intake was expressed on a percent body weight basis, steers on rangeland consumed more $(P<0.10)$ than steers grazing tall fescue (Table 3 ). Reduced ability of the animals grazing tall fescue to graze selectively, may cxplain the lower voluntary intakes of thesc animals since tall fescue pastures were the most highly utilized. Forbs and Hodgson (1985) indicated rate of intake is related to sward characteristics. Animals grazing pastures with sufficient available forage are subject to minor sward changes compared with animals grazing areas of limited forage availability. No differences were observed in in vitro organic matter digestibility among the pasture types $(P>0.10$; Table 3$)$.

\section{Summer}

Protein components (crude protein, acid detergent insoluble nitrogen, available crude protein) were not different $(P<0.10)$ among the summer pastures (Table 2). Fiber components (neutral detergent fiber, acid detergent fiber, and acid detergent lignin) were similar $(P>0.10)$ between bermudagrass and bluestem. However, rangeland pastures were higher in neutral detergent fiber and acid detergent fiber $(P<0.10)$ than bermudagrass and bluestem pastures. Acid detergent lignin was similar among all pastures $(P>0.10$; Table 2$)$. When intake was expressed on an organic matter basis, no differences were observed $(P>0.10)$. However, when consumption was expressed on a dry matter basis as percent of body weight, steers grazing rangeland pastures con-

PTable 2. Chemical composition (organic matter basis) of ingesta from steers grazing irrigated grass or rangeland pastures during 1990.

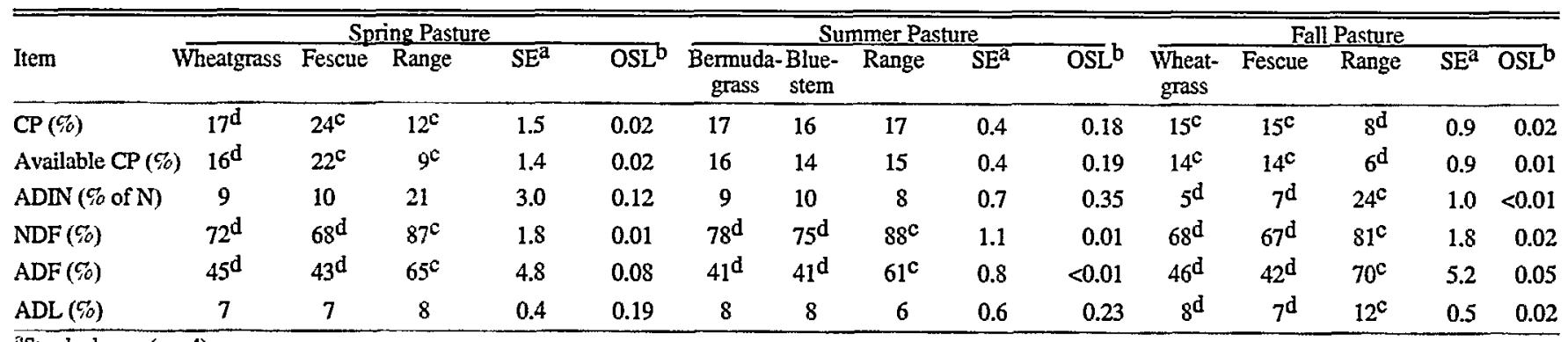

astandard error $(\mathrm{n}=4)$.

bobserved significance level.

cde Row values with different superscripts differ. 
Table 3. Intake and in vitro organic matter disappearance (IVOMD) of steers grazing irrigated grass or rangeland pastures during 1990.

\begin{tabular}{|c|c|c|c|c|c|c|c|c|c|c|c|c|}
\hline \multirow[b]{2}{*}{ Item } & \multicolumn{4}{|c|}{ Spring Pasture } & \multicolumn{4}{|c|}{ Summer Pasture } & \multicolumn{4}{|c|}{ Fall Pasture } \\
\hline & Wheatgrass & Fescue & Range & $S E^{\mathrm{a}}$ & Bermudagrass & Bluestem & Range & $\mathrm{SE}^{\mathrm{a}}$ & Wheatgrass & Fescue & Range & $\mathrm{SE}^{\mathrm{a}}$ \\
\hline \multicolumn{13}{|l|}{ Dry matter basis } \\
\hline Intake (kg) & 5.7 & 5.3 & 6.6 & 0.7 & 7.1 & 7.8 & 8.4 & 0.4 & 6.5 & 5.3 & 7.2 & 0.9 \\
\hline \multicolumn{13}{|c|}{ Organic matter basis } \\
\hline Intake $(\mathrm{kg})$ & 4.6 & 3.7 & 4.8 & 0.4 & 5.8 & 6.6 & 5.9 & 0.4 & 5.0 & 4.2 & 5.3 & 0.7 \\
\hline Intake (\% BW) & $1.7^{\mathrm{b}, \mathrm{c}}$ & $1.3^{\mathrm{c}}$ & $2.3^{\mathrm{b}}$ & 0.2 & 1.8 & 2.2 & 2.7 & 0.2 & 1.5 & 1.1 & 1.9 & 0.2 \\
\hline
\end{tabular}

astandard error $(n=4)$.

bed Row values with different superscripts differ.

sumed more $(P<0.05)$ than steers on either bermudagrass or bluestem pastures (Table 3 ). This is a reflection of a higher ash content on the rangeland pastures. When corrected for ash (expressed on organic matter basis) no differences were observed. Differences $(P<0.05)$ were detected between all pastures for in vitro organic matter digestibility (Table 3 ) with rangeland pastures having the highest in vitro organic matter digestibility $(73 \%)$, followed by bluestem (69\%) and bermudagrass $(65 \%)$. The observation that steers on rangeland pastures had the highest in vitro organic matter digestibility may relate to the animals ability to selectively graze different plant species. With a variety of warm-season grasses the steers may have been better able to select a quality diet. Ease of which a forage is prehended is an important factor affecting voluntary intake (McLeod and Smith, 1989). Burns et al. (1991) reported bermudagrass has an inferior canopy structure that limits the animals ability to select a diet of high in vitro organic matter digestibility, and this led to a reduced dry matter intake. Results reported herein tend to agree with that hypothesis. Although not different, steers grazing bermudagrass pastures had a tendency of decreased intake and lower in vitro organic matter digestibility.

\section{Fall}

No differences were detected $(P>0.05)$ between wheatgrass and tall fescue for any chemical components measured in the ingesta samples. Differences were observed, however, between the cool-season pastures and rangeland pastures $(P<0.05$; Table 2). Rangeland pastures were lower in crude protein and available crude protein, and higher in acid detergent insoluble nitrogen and all fiber components (Table 2). Voluntary intake was similar among all pastures ( $P>0.05$; Table 3 ). Rangeland pastures did, however, have the lowest in vitro organic matter digestibility $(P<$ 0.05 ), but tall fescue and wheatgrass were similar ( $P>0.05$; Table 3).

\section{Animal Performance}

Steers grazing winter wheat had greater $(P<0.05)$ gain than steers grazing rangeland pastures (Table 4 ). Since the rangeland pastures were primarily made up of warm-season grasses, forage available to steers consisted predominantly of dormant grass species. Therefore, it is not surprising that steers grazing winter wheat had much higher gains than steers grazing rangeland pastures. In fact, steers on rangeland pastures were only able to maintain their initial weight, which further suggests a low quality diet, even though limited protein supplementation did occur.

Animal performance data during the spring were only com- pared when steers were grazing cool-season pastures simultaneously (i.e., 10 April-30 May), even though steers grazing wheatgrass pastures remained on these pastures for an additional 28days. Animal performance was not different among steers grazing tall fescue, wheatgrass, or rangeland pastures during the spring grazing period ( $P>0.05$; Table 4$)$. Forage dry matter yield however, was considerable greater $(P<0.05)$ for wheatgrass than tall fescue $(4,993,1,637 \mathrm{~kg}$ dry matter/ha; Table 4$)$. Steers grazing tall fescue pastures were moved to warm-season (bermudagrass) pastures 28-days earlier than steers grazing wheatgrass since tall fescue pastures were low yielding and could not support grazing with acceptable gains for the additional 28-days. At the same time, bermudagrass pastures were rapidly growing and could sustain grazing and wheatgrass pastures still had abundant available forage for steers to graze these pastures longer.

Steer performance during the summer was again compared only when steers were grazing warm-season pastures simultaneously. Performance of steers grazing bermudagrass, bluestem, and rangeland pastures were similar $(P>0.05)$, although steers grazing bluestem tended to gain less $(59 \mathrm{~kg})$ than steers grazing bermudagrass $(72 \mathrm{~kg}$ ) and rangeland (72 $\mathrm{kg}$; Table 4). Bermudagrass pastures produced almost twice as much forage as bluestem $(P<0.05$; Table 4$)$. It should be remembered this was the first grazing year for the bluestem pastures, as these pastures were established one year later than the bermudagrass pastures. Grazing pressure was intentionally reduced to insure stand establishment. Therefore, these data may not reflect the true yielding potential of the bluestem pastures. As mentioned earlier, rangeland pastures were primarily made up of warm-season grasses. With a variety of warm-season grasses the steers may have been better able to select a quality diet. This is reflected in the steers gain.

Steers grazing tall fescue in the fall had the highest gain followed by those on wheatgrass, and rangeland pastures $(45,33,22$ $\mathrm{kg}$, respectively; Table 4). These findings agree with Wallace and Williams (1979) who reported animal performance favored tall fescue over wheatgrass. Also, since rangeland pastures were primarily comprised of warm-season grasses, a decline in animal performance would be expected. Forage dry matter yield was similar $(P>0.10)$ between tall fescuc and wheatgrass, although strong tendencies were observed for greater forage production from the wheatgrass pastures.

\section{Over Seasons}

The quality of the rangeland pastures was higher during the spring and summer as indicated by increased crude protein and in 
Table 4. Steer gains (kg) and forage dry matter yields (kg/ha) by season and forage type for 1990.

\begin{tabular}{|c|c|c|c|c|}
\hline $\begin{array}{l}\text { Season } \\
\text { and item }\end{array}$ & & Pasture & & $S E^{\mathrm{a}}$ \\
\hline $\begin{array}{l}\text { Winter } \\
\text { Gain (kg) }\end{array}$ & $\begin{array}{l}\text { Range } \\
8^{\mathrm{c}}\end{array}$ & $\begin{array}{l}\text { Wheat } \\
\qquad 90^{\mathrm{b}}\end{array}$ & & 4.7 \\
\hline $\begin{array}{l}\text { Spring } \\
\text { Gain (kg) } \\
\text { Yield (kg/ha) }\end{array}$ & $\frac{34}{-}$ & $\begin{array}{r}\text { Fescue } \\
36 \\
1637^{\mathrm{c}}\end{array}$ & $\begin{array}{r}\text { Wheatgrass } \\
38 \\
4993^{b}\end{array}$ & $\begin{array}{c}2.6 \\
554\end{array}$ \\
\hline $\begin{array}{l}\text { Summer } \\
\text { Gain }(\mathrm{kg}) \\
\text { Yield }(\mathrm{kg} / \mathrm{ha})\end{array}$ & 72 & $\begin{array}{c}\text { Bermuda } \\
72 \\
8451^{d}\end{array}$ & $\begin{array}{r}\text { Bluestem } \\
59 \\
4837^{\mathrm{e}}\end{array}$ & $\begin{array}{c}4.8 \\
563\end{array}$ \\
\hline $\begin{array}{l}\text { Fall } \\
\text { Gain (kg) } \\
\text { Yield (kg/ha) }\end{array}$ & $2^{22^{b}}$ & $\begin{array}{c}\text { Fescue } \\
45^{f} \\
651\end{array}$ & $\begin{array}{r}\text { Wheatgrass } \\
33 \mathrm{~g} \\
1036\end{array}$ & $\begin{array}{c}3.9 \\
382\end{array}$ \\
\hline
\end{tabular}

astandard crror, $n=8$ (gain) or 12 (yield).

bc Row values differ $(P<0.05)$.

dis Row values differ $(P<0.01)$

fgh Row value differ $(P<0.10)$

vitro organic matter digestibility, and decreased acid detergent lignin. During the fall and winter, these pastures were higher in fiber components and lower in in vitro organic matter digestibility and crude protein. Fiber components (neutral detergent fiber and acid detergent lignin) did not differ $(P>0.05)$ between the spring and fall for the tall fescue pastures; however, crude protein and in vitro organic matter digestibility were greater $(P<0.05)$ during spring vs the fall, indicating higher quality during the spring growing season. Similar results were found for wheatgrass pastures. In vitro organic matter disappearance was greater $(P<$ 0.10 ) in the spring compared to the fall. Crude protein was not different between scasons, but did tend to be greater during the spring season. Fiber components did not differ over the spring and fall $(P>0.10)$. Steers in the rotation groups fescue-bermudagrass-fescue gained more $(P<0.10)$ year-long than other groups. Forage dry matter also was greater for this rotational groups which would allow for more beef production per ha.

\section{Conclusions and Management Implications}

The cool-season grasses; Jose tall wheatgrass and Johnstone tall fescue, appeared to be similar in terms of quality, although fescue was higher in crude protein in the spring months. Jose tall wheatgrass pastures must be stocked at levels great enough to prevent growth from becoming stemmy and rank which may diminsh the forage quality while fescue must be stocked lighter to insure production. Both warm-season grasses, Hardie bermudagrass and Ironmaster old world bluestem, yielded forage of equal quality in terms of protein and fiber content, but bluestem did have a higher digestibility. This is most likely due to the canopy structure of bluestem. Bluestem has a higher canopy in which the top portion is primarily made up of leaf. This allows the animals greater access to the more digestible canopy fractions. The canopy structure of bermudagrass is low to the ground and contains a high proportion of stem, and less digestible plant fragments throughout the canopy. Therefore, the structure is not conducive to high digestibility. Imposed management practices should provide enough animals to maintain grasses in an actively growing, vegetative stage in order to maintain maximum forage quality.
Rangeland and tame pastures proved to be of comparable quality in the spring and summer. However, stocking rates on rangeland must be light to prohibit selective grazing pressure on limited quantities of preferred cool-season species. Livestock numbers capable of grazing native rangeland in summer, fall, and winter frequently put excessive pressure on the pastures during the spring growth. Development of grazing strategies to reduce the pressure are limited. Use of tame pasture can alleviate the difficulty in management. Results show tame pasture grasses to be a viable alternative, especially with cow/calf production by providing opportunities for rangeland deferment in the spring and also during the growing season.

Further study will more fully define forage quality and quantity of tame pasture species needed to optimize different animal/pasture management strategies.

\section{Literature Cited}

AOAC. 1984. Official method of analysis. 14th ed. Assoc. of Anal. Chem., Washington, D.C.

Barlow, R., K. J. Ellis, P. J. Williamson, P. Costigan, P. D. Stephenson, G. Rose, and P. T. Mears. 1988. Dry-matter intake of Hereford and first-cross cows measured by controlled release of chromic oxide on three pasture systems. J. Agr. Sci., (Camb.). 110:217.

Burns, J. C., K. R. Pond, and D. S. Fisher. 1991. Effects of grass species on grazing steers: II. Dry-matter intake and digesta kinetics. J. Anim. Sci. 69:119.

Burritt, E. A., J. A. Pfister, and J. C. Malechek. 1988. Affect of drying method on the nutritive composition of esophageal fistula samples: Influence of maturity. J. Range Manage. 41:346.

Fales, S. L. 1986. Effects of temperature on fiber concentration, composition, and in vitro digestion kinetics of tall fescue. Agron. J. 78:963.

Fisher, D. S., J. C. Burns, K. R. Pond, R. D. Mochrie, and D. H. Timothy. 1991. Effects of grass species on grazing steers: I. Diet composition and ingestive mastication. J. Anim. Sci. 69:1188.

Forbes, T. D. A., and J. Hudgson. 1985. Comparative studies of the influence of sward conditions on the ingestive behavior of cows and sheep. Grass and Forage Sci. 40:69.

Ford, C. W., I. M. Morrison, and J. R. Wilson. 1979. Temperanure effects on lignin, hemicellulose, and cellulose in tropical and temperate grasses. Aust. J. Agr. Res. 30:621.

Funk, M. A., M. L. Galyean, M. E. Branine, and L. J. Krysl. 1987. Steers grazing blue grama rangeland throughout the growing season. I. Dietary composition, intake, digesta kinetics and ruminal fermentation. J. Anim. Sci. 65:1342.

Galyean, M. L. 1988. Laboratory Procedures in Animal Nutrition Research. Dept. of Animal and Range Sciences. New Mexico State Univ., Las Cruces.

Goering, H. K., and P. J. Van Soest. 1970. Forage fiber analysis (apparatus, reagents, procedures and some applications). USDA-ARS Handb. 379. ARS, USDA, Washington, D.C.

Button, J. B. 1963. Studies on the nutritive value of new Zealand dairy pastures. II. Herbage intake and digestibility studies with dry cattle. New Zealand J. Agr. Res. 5:409.

Karn, J. F. 1986. Microwave-oven drying of forage samples collected via esophageal fistula. J. Anim. Sci. 63:595.

Kattnig, R. M. 1991. Evaluation of range beef cattle production efficicncy under semi-desert conditions. Ph.D. Diss.. New Mexico State Univ., Las Cruces pp 16.

Kirksey, R. E., H. E. Kiesling, and M. Ortiz. 1991. Steer performance on irrigated pastures at Tucumcari, New Mexico. New Mexico State Univ. Agr. Exp. Sta. Res. Rep. 654. 
Kloppenburg, P. B., H. E. Kiesling, G. B. Donart, R. E. Kirksey, and R. M. Kattnig. 1990. Effects of drying method on chemical composition of fresh forages. Proc. Western Sec. Amer. Soc. Anim. Sci. 41:102.

Laby, R. H., C. A. Graham, S. R. Edwards, and B. Kautzner. 1985. A controlled release intraruminal device for the administration of fecal dry-matter markers to the grazing ruminant. Can J. Anim. Sci. 64 (Suppl.):337.

McCollum, F. T., M. L. Galyean, L. J. Krysl, and J. D. Wallace. 1985. Cattle grazing blue grama rangeland. I. Seasonal diets and rumen fermentation. J. Range Manage. 38:539.

Mcleod, M. N., and B. R. Smith. 1989. Eating and ruminating behavior in cattle given forages differing in fiber content. Anim. Prod. 48:503.

Rosiere, R. E. 1978. Voluntary intake of forage and roughage in beef females. Doctoral Diss., New Mexico State Univ., Las Cruces.
SAS. 1985. SAS User's Guide: Statistical Analysis System Institute, Inc., Cary, N.C.

Steel, R. G. D., and J. G. Torrie. 1980. Principles and procedures of statistics. McGraw-Hill Book Co. N.Y.

Tilley, J. M. A., and R. A. Terry. 1963. A two-stage technique for the in vitro digestion of forage crops. J. Brit. Grassl. Soc. 18:104.

Wallace, J. D. and D. H. Williams. 1979. Animal performance on Alta fescue, Jose wheatgrass, or Potomac orchardgrass pastures in northeastern New Mexico. New Mexico State Univ. Agr. Exp. Sta. Res. Rep. 404.

Williams, C. H., D. J. David, and O. Ilsma. 1962. The determination of chromic oxide in faeces samples by atomic absorption spectrophotometry. J. Agr. Sci. (Camb.). 59:381. 